\title{
AN INQUIRY INTO THE HISTORY OF THE ADJUDICATION OF MERCANTILE DIS- PUTES IN GREAT BRITAIN AND THE UNITED STATES*
}

\author{
WIILTAM C. Jones† \\ INTRODUCTION
}

\begin{abstract}
$\mathrm{A}^{\mathrm{sn}}$ ITHOUGH the law merchant has been studied by English and American lawyers for several centuries, at least since it was supposedly "assimicommon law rules that have been the primary center of interest. It is generally known that there were, in the middle ages, certain special merchants' courts that handled mercantile cases and applied the law merchant. It is also known that these courts had substantially disappeared by the 18th century, and it is generally believed that it then became necessary for the common-law courts to take jurisdiction of the cases that the mercantile courts had previously handled. As the common-law courts had no body of law applicable to such cases, they had to assimilate the law that applied to these cases-the law merchant -into the common law. This job of assimilation was supposedly accomplished by Lord Mansfield while he was Chief Justice of the Court of King's Bench.

A classic statement of this history was made by Justice Scrutton. ${ }^{1} \mathrm{He}$ wrote:
\end{abstract}

Now if we follow the growth of this Law Merchant or Mercantile Law, which was two hundred years ago distinct from the Common Law, we find it in England going through three stages of development. The first stage may be fixed as ending at the appointment of Coke as Lord Chief Justice in the year 1606, and before that time you will find the Law Merchant as a special law administered by special Courts for a special class of people. .. . The second stage of development of the Law Merchant may be dated from Lord Coke's taking office in 1606, and lasts until the time when Lord Mansfield became Chief Justice in 1756, and during that time the peculiarity of its development is this: That the special Courts and the Law Merchant is administered by the King's Courts of Common Law, but it is administered as a custom and not as

* This study was made as a part of the research on commercial arbitration being conducted by the University of Chicago Law School under a grant from the Ford Foundation.

$\dagger$ Assistant Professor of Law, Washington University Law School.

${ }^{1}$ Scrutton, General Survey of the History of the Law Merchant, 3 Select Essays in AngloAmerican Legal History 7 (1909).

${ }^{2}$ Id., at 9. 
law, and at first the custom only applies if the plaintiff or defendant is proved to be a merchant. . . . As the Law Merchant was considered as custom, it was the habit to leave the custom and the facts to the jury without any directions in point of law, with a result that cases were rarely reported as laying down any particular rule, because it was almost impossible to separate the custom from the facts; as a result little was done towards building up any system of Mercantile Law in England. The construction of that system began with the accession of Lord Mansfield to the Chief Justiceship of the King's Bench in 1756, and the result of his administration of the law in the Court for thirty years was to build up a system of law as part of the Common Law, embodying and giving form to the existing customs of merchants. ... ${ }^{3}$ Since the time of Lord Mansfield other judges have carried on the work that he began, ... and as the result of their labours the English Law is now provided with a fairly complete code of mercantile rules, and is consequently inclined to disregard the practice of other countries. ${ }^{4}$

The principal point to be drawn from this statement is the implicit assumption that, upon the assimilation of certain doctrines into the common law, the cases to which these doctrines applied were brought in common law courts. This, however, is not so. Lord Mansfield, for example, decided only one sales case involving warranty of quality in over 30 years on the bench. ${ }^{5}$ In the next century Blackburn, one of the leading commercial judges, decided only 26 cases involving the interpretation of sales contracts and quality disputes during more than 30 years on the bench at the height of England's commercial dominance of the world. ${ }^{6}$ Indeed, it may be wondered what the merchants did during the century and one-half between the time when the fair court disappeared and Lord Mansfield began the assimilation of the Law Merchant into the common law.

Merchants did not turn exclusively to their own special courts during the Middle Ages. It is nevertheless true that mercantile cases have always, in one way or another, been decided by merchants. In earlier times this was accomplished by a court referring a case to merchant referees or arbitrators or to a jury of merchants. More recently, merchants have provided their own proceedings, generally called (somewhat misleadingly) arbitration. The first step in any study of the development of the rules of mercantile law should be a consideration of what forums have actually been, and are being, used by merchants for the adjudication of their disputes. Thus, what is attempted here is to give a brief outline of the ways in which merchants have settled their disputes in England and the United States from the Middle Ages to the beginning of this century.

3Id., at 12, 13.

4Id., at 15. Another statement of this position is found in 1 Holdsworth, History of English Law 526-73 (4th ed., 1931).

${ }^{5}$ Ilewellyn, On Warranty of Quality and Society, 36 Col. L. Rev. 699,701 (1936). See also, Llewellyn, Across Sales on Horseback, 52 Harv. L. Rev. 725, 740-46 (1939).

${ }^{6}$ This information was furnished by Mr. Norman I. Miller, Research Associate at the University of Chicago Law School, who has made a study of all of Blackburn's cases. 
Mercantile Tribunats IN England, 1100-1800

THE MIEDIEVAL PERIOD

The initial development of special mercantile tribunals is easy to understand. Medieval England was, like the rest of Europe, a feudal society, opredominantly military and agricultural. ${ }^{7}$ Consequently, groups of people whose primary occupation was something other than farming or fighting, especially if they lived in the towns, tended inevitably to be set apart from the majority of the nation. Merchants were such a group; so were miners, scholars, members of the clergy, and mariners. Many of these groups had special courts in which their disputes, at least those among themselves, were settled. Thus, there was a very complicated set of ecclesiastical courts; ${ }^{8}$ also university courts, ${ }^{9}$ maritime courts, ${ }^{10}$ and stannary courts which had jurisdiction over miners in the counties of Cornwall and Devonshire. ${ }^{11}$ There were many other special courts, ${ }^{12}$ among these were those for merchants, such as the fair courts or courts of pie-powder. ${ }^{13}$

Fairs were probably the most important means of trade in Europe during the medieval period. ${ }^{14}$ Since transportation was difficult, the means of communication primitive in the extreme, and towns and cities small, 15 it was essential that there be a central market at which a merchant could find a buyer for his goods and also acquire different goods to trade elsewhere. Fairs supplied this need, though they varied greatly in size and importance. Probably the most important one in Europe was that held at Champagne near Paris. It lay on the principal north-south route, and there merchants from the South, with the various valuable Mediterranean goods, especially spices, disposed of their wares to merchants who had the cloth of the Low Countries to offer in exchange. The fairs were rarely held more than once or twice a year at the same place. Most were much more limited in scope than the fair at Champagne, but no matter how local, they are to be distinguished from the town markets which supplied the local needs. As a consequence, in addition to their use as places for the exchange of goods, fairs also served as money marts for the settlement of accounts.

In England, and presumably on the Continent as well, the right to hold a fair was within the power of the King. One of the incidents of the grant of a

\footnotetext{
7 Clapham, A Concise Economic History of Britain, 77-80 (1949); 1 Lipson, Economic History of England 163-65 (5th ed., 1929).

81 Holdsworth, op. cit. supra note 4, at 598-614.

${ }^{9} \mathrm{Id}$., at $165-76 . \quad{ }^{10} \mathrm{Id}$., at 544-73. $\quad 11 \mathrm{Id}$, at 151-65.

12 For example, the court of the Constable and Marshall, 1 Holdsworth, op. cit. supra note 4 , at 573-80, and the courts of the forest, id., at 97-99.

${ }^{13}$ Id., at 526-44, 552-59, 568-73.

14 Pirenne, Economic and Social History of Medieval Europe 97-103 (1936).

${ }^{15}$ It has been estimated that between the 12 th and 15 th centuries the urban population of Europe was never more than ten per cent of the total population. Id., at 58-9.
} 
fair franchise by the King was the right to hold a court. These courts had jurisdiction over all matters, civil and criminal, which took place within the temporal and geographical limits of the fairs except for pleas of land and serious crimes. ${ }^{16}$ Accordingly, one of the matters these courts-called courts of pie-powder-were called upon to administer was the mercantile dispute. In the adjudication of these disputes the courts turned to the law merchant, ${ }^{17}$ a system of legal and equitable principles derived from many sources, including Roman Law. ${ }^{18}$ Its development throughout Europe was quite similar. This was natural since merchants at the time formed a European community that was in many ways international-especially in England where almost all foreign trade was in the hands of aliens, chiefly Germans and Italians. ${ }^{19}$ Further, the needs of merchants were peculiar to themselves and very different from those of the remainder of the community. Consequently, the merchants would be expected to have a special law common throughout Europe regarding activities in which only they engaged. The law merchant was not, however, at this time, a clear and definite body of doctrine like canon law or the Roman Law. ${ }^{20}$ The important thing about these fair courts was not, however, that they applied the law merchant, although they did, but that their decisions were actually made by merchants. "[T]he merchants were the suitors or doomsmen; they found the judgment or declared the law."21 Consequently, the law applied would be the local mercantile understanding of what the law of the particular situation was.

There were other courts almost identical to fair courts, called courts of the staple. These were instituted in the towns of the staple, which, by statute, were the only authorized ports of entry and export for certain commodities such as wool, woolfels, leather, tin and lead. ${ }^{22}$ They were established as a measure for the control of trade and the collection of customs. The courts of

${ }^{16}$ As to England, see 1 Selden Society, Select Cases Concerning the Law Merchant xvi (Gross ed., 1908); as to France, see Morel, Les Jurisdictions Commerciales au Moyen-Age 148-49 (1897).

${ }^{17} 1$ Selden Society, op. cit. supra note 16, at xvï-xviii. The name "pie-powder" was given to this court "because the court was frequented by chapmen with dusty feet, who wandered from mart to mart." Id., at xiv.

${ }^{18}$ Burdick, What is the Law Merchant, 3 Select Essays in Anglo-American Legal History 34 (1909); Isaacs, The Merchant and His Law, 23 J. Pol. Econ. 529, 530-38 (1915); Wolaver, The Historical Background of Commerical Arbitration, 83 U. of Pa. L. Rev. 132, 135-38 (1934); Sanborn, Origins of the Early English Maritime and Commerical Law 324-407, especially 325-27 (1930).

191 Lipson, op. cit. supra note 7, at 448-71.

${ }^{20}$ See 17 Stuart, The Law Merchant in England in the Seventeenth and Eighteenth Centuries, Transactions of the Royal Historical Society, 4th Series, 149 (1934); Isaacs, op. cit. supra note 18 , at 529 .

211 Selden Society, op. cit. supra note 16, at xxv.

221 Holdsworth, op. cit. supra note 4, at 540-44; Jenckes, The Origin, the Organization and the Location of the Staple of England 5-24 (1908). 
the staple sat more or less continuously, unlike the fair courts, which sat only while the fairs were in session. Otherwise there was little difference in their structure, the law they enforced, or their suitors. ${ }^{23}$

The Statute of the Staple ${ }^{24}$ provided that

... all merchants coming to the staple . . . shall be ruled by the law-merchant, of all things touching the staple, and not by the common law of the land, nor by usage of cities, borough, or other towns; ... And for that merchants may not often tarry long in one place ... we will and grant that speedy right be done to them from day to day and hour to hour ... in every town where the staple is ordained, a mayor good, lawful, and sufficient, shall be made and established, having knowledge of the law-merchant, to govern the staple, and to do right to every man after the laws aforesaid... And in every place where the staple is, shall be two conveniable constables . . . chosen by the commonalty of the merchants of the said places: ... and that no mayor hold the office over one year unles he be newly chosen by the commonalty of the merchants, as well of strange strangers as of denizens ... the merchants strangers shall chus two merchants strangers, whereof the one towards the south, and the other towards the north, shall be assigned to sit with the mayor and constables of the staples . . . to hear the plaints touching merchants aliens....

Thus, in the staple courts as in the fair courts, the merchants in effect decided, or were very influential in deciding, their own cases. Indeed, the mercantile population elected the officials-the mayor and constables-who constituted the courts.

Merchants were by no means restricted to the use of these special courts for the decision of mercantile disputes. Merchants, both foreign and domestic, employed the borough courts, ${ }^{25}$ among them the courts of London. ${ }^{26}$ When one of the parties was an alien a jury de mediatate linguae, one composed onehalf of aliens, was employed as a matter of right. ${ }^{27}$ Since almost all mer-

231 Holdsworth, op. cit. supra note 4, at 540-44; 1 Selden Society, op. cit. supra note 16 at xxvii; 1 Gross, The Gild Merchant 140-47 (1890).

$2427 \mathrm{Edw}$. III c. 2 (1353).

${ }^{25}$ See 1 Selden Society, op. cit. supra note 16 , at $x x$-xxii. See also 1 Holdsworth, op. cit supra note 4, at 535-40; 1 Selden Society, Borough Customs 201 (Bateson ed., 1904) ("And if inquest be joined between denizen and foreigner, it shall be made by twelve men, of whom half shall be denizen and the other half foreigners dwelling in the town, if it be a case of contract, debt, or trespass, whereof foreign merchants can have cognisance." [London Borough custom, 1285]); 1 id., at 201-5 (debts to be proved by tallies in London, Hastings, Hereford, and Lincoln); 2 id., at Ixvii-Lxxx (contract); 2 id., at 183-92 (instances of merchant and fair law in London, Bristol, Ipswich, Waterford, Cork, Dublin, Kilkenny, Norwich, Torksey, and Rye).

${ }^{25}$ See note 25 supra. See also, Calendar of Plea and Memoranda Rolls of the City of London 1323-1361 vii, 263 (Thomas ed., 1926); Calendar of Plea and Memoranda Rolls of the City of London 1354-1381 248, 263, 277, 283-84 (Thomas ed., 1929); Calendar of Plea and Memoranda Rolls of the City of London 1413-1437 xvi, 10, 14-15, 69, 169, 179, 209-10 (Thomas ed., 1943).

${ }^{27}$ Calendar 1323-1364, op. cit. supra note 26, at 259; Calendar 1413-1437, op. cit. supra note 26 , at 91 . 
chants were aliens, this was obviously a means by which merchants decided their own cases. This same device was used when alien merchants used the principal common-law courts. Not infrequently in a later period juries of merchants were employed even in cases where neither party was an alien. ${ }^{28}$ Merchants also used the Admiralty Court. This court had not attained, however, at this time, any stability and seemed to wax and wane in size and importance. It decided some mercantile cases, the details of which are unknown, which were referred by the court to mercantile arbitrators for decision. ${ }^{29}$ Since the main growth of the Admiralty Court was in the Tudor period, its contribution will be discussed later. Another tribunal employed by merchants was the town gild, since nearly all of the domestic merchants who lived in towns were members of the gild merchants of the town in which they lived. These gilds generally controlled trade in the town and provided a forum for settling disputes in matters of trade among their members. ${ }^{30}$

It would seem, then, fair to say, that in the Middle Ages in England the merchant had available a great variety of forums wherein he could enforce his rights, with merchants deciding his case. This is not to say that merchants never had trouble with the common law or had cause to wish for courts more suited to their needs. Doubtless the English judicial system, including the courts which specialized in mercantile disputes, from time to time failed utterly to accommodate the needs of the merchants. By and large, however, the needs of the merchants were recognized, and more or less suitable forums were available to them.

THE TUDOR-STUART MONARCHY, I500-I640

The commercial situation described in the medieval period continued into the Tudor period although the particular institutions used were different. English society and trade were changing, and this change manifested itself widely. As was indicated, during the medieval period England's foreign trade was carried on predominantly by aliens. This condition began to change, however, and by the beginning of the Tudor regime, a native English mercan-

${ }^{28}$ As to the jury de'mediatate lingnae in the court of King's Bench, see Beardwood, Alien Merchants in England 1350 to 137777 (1931). Foreign merchants evidently had frequent recourse to the common-law courts. In a somewhat later period, but probably reflecting an earlier practice, a jury of merchants was demanded by a party and granted by the court with no indication that the moving party was an alien. "The court was moved that a jury of merchants might be returned to try an Issue between two merchants, touching Merchants Affairs, and it was granted: Hill, 21 Car. B. R. Because it was conceived they might have better Knowledge of the Matters in Difference which were to be tried than others could, who were not of that Profession." See also 2 Lilly, Practical Register 154 (2d ed., 1735); Lord Mansfield's use of this device is the famous one, Fifoot, Lord Mansfield 104-6 (1936), but he was only employing an old device for his purposes.

291 Holdsworth, op. cit. supra note 4 , at 544-49; 1 Selden Society, Select Pleas in the Court of Admiralty xiv, xix, xxii, liv (Marsden ed., 1894).

${ }^{30} 1$ Gross, The Gild Merchant 64-6 (1890). 
tile class had grown up and taken over most of the trade. Furthermore, the nature of trade had changed. For one thing, England ceased to have a "colonial" economy, that is, one in which she furnished wool and other raw materials to the Continent in return for finished goods of various kinds. Instead, England had become a manufacturer and exporter of finished goods, especially cloth. ${ }^{31}$ Further, the mechanics of trade had changed. Merchants had become sedentary, established in one place from which they dispatched ships with goods to trade at other places, rather than wanderers around Europe who traded as they went. ${ }^{32}$ Fairs ceased, gradually to be sure, to be very important for trade, and the institution of the staple disappeared entirely. ${ }^{33}$ Merchants began to be organized into companies to trade in increasingly distant places from India to Russia. ${ }^{34}$ The organization of government was also changing. The Tudor monarchy created new organs of government for the greater control of every aspect of life including the courts. Notable among these were the Council, and its off-shoot, the Star Chamber. ${ }^{35}$

All of these developments were reflected in the ways merchants settled their disputes. The fair courts decreased in importance, and the staple courts disappeared. ${ }^{36}$ The Admiralty Court increased greatly in importance and began to handle commercial cases. ${ }^{37}$ Many mercantile cases also went to the Council and the Star Chamber, ${ }^{38}$ and, probably, to the Chancery and the common-law courts. $^{39}$ Mercantile cases that were brought to trial were generally decided by reference to merchants as arbitrators or by the use of merchant juries. It seems probable that the lesser common law courts in the towns, especially the Mayors' Courts in the more important ports, particularly London, were more

3I 2 Cambridge Economic History 232-51, 413-28 (1952); 1 Lipson, op. cit. supra note 7, at 444 et seq.; 2 id., at 184-96.

${ }^{32}$ See note 31 supra. See also Gras, Business and Capitalism 67 et seq. (1939).

${ }^{33}$ As to fairs, see 1 Selden Society, op. cit. supra note 16, at xix; as to the staple, see Jenckes, The Origin and Organization and the Location of the Staple of England 54-7 (1908); see also 1 Holdsworth, op. cit. supra note 4, at 570, 571 .

${ }^{34}$ For a discussion of the Russian and Baltic trade, see Gerson, Vaughn, and Deardorff, Studies in the History of English Commerce in the Tudor Period (1912); for a general discussion of the trading companies, see Hewins, English Trade and Finance Chiefly in the Seventeenth Century 24-73 (1892); Selden Society, Select Charters of Trading Companies xi-cxxxvi (Carr ed., 1913); 2 Lipson, op. cit. supra note 7, at 184 et seq.

${ }^{35} 1$ Holdsworth, op. cit. supra note 4 , at 477-516; 4 id., at 60-108; 5 id., at 155.

${ }^{36}$ See note 33 supra.

371 Holdsworth, op. cit. supra note 4, at 571; 5 id., at 137-39; 1 Selden Society, op. cit. supra note 29 , at lxvii; 2 id., at xliii-xliv.

${ }^{38} 1$ Holdsworth, op. cit. supra note 4, at 571; 5 id., at 135-37; see also Dawson, The Privy Council and Private Law in the Tudor and Stuart Periods I, 48 Mich. L. Rev. 393, 406-10 (1950); 2 Hargrave, Collectanea Juridica 1-239 (1791).

${ }^{39} 5$ Holdsworth, op. cit. supra note 4 , at $139-48$. 
used by merchants than the courts at Westminster. ${ }^{40}$ These lesser courts almost certainly enforced the law merchant. The Court of Requests, a sort of poor-man's Court of Chancery, seems also to have acted in much the same way by referring mercantile cases to mercantile arbitrators. ${ }^{41}$

Although almost all of the non-ecclesiastical courts, both common-law and prerogative, were used by merchants during this period, it seems that the central common-law courts were becoming less hospitable to mercantile cases than they had been in an earlier time. ${ }^{42}$ This was due perhaps to the fact that they were finding it necessary to fight for their supremacy, or even survival, and accordingly emphasized their antiquity and their unchanging nature. Previously unthreatened, and perhaps less powerful, they had been much more flexible and had not made much effort to define their powers and the nature of the law they enforced, proceeding in that condition of happy muddle which is supposed to be so typically English. In the latter part of Elizabeth's reign and in those of the first two Stuarts, however, the common law courts had to define exactly what they did and how they did it in order to show that their rivals, such as Admiralty and Star Chamber, could not take jurisdiction of a particular type of case. ${ }^{43}$ There was some effort made during this period to establish a special merchant's court. Indeed, a commission composed of the recorder of London, two doctors of the civil law, two common-law lawyers, and "eight grave and discreet merchants" was established "for the hearing of causes arising and policies of assurances, such as now are or hereafter shall be entered

${ }^{40}$ The writer has not located any materials for this precise period. However, it may be recalled that there is much evidence of the use by merchants of the Lord Mayor's Court of London in the 15 th century (note 26 supra) and there is similar evidence for the latter part of the 17 th century (note 54 infra). Consequently, it seems fairly safe to assume that there was no sharp break in the 16 th and early 17 th centuries. As to the importance generally of local courts in the study of English (and American) legal history, see Goebel, King's Law and Local Custom in Seventeenth Century New England, 31 Col. I. Rev. 416 (1931). Holdsworth states that the local courts were insignificant in the 16th century as compared to their former status. 5 Holdsworth, op. cit. supra note 4 , at 151 . In many fields this may have been true, but in mercantile matters, it is believed that it was not.

411 Holdsworth, op. cit. supra note 4, at $412-16 ; 5$ id., at 139.

${ }^{42}$ This is, of course, very uncertain, and is, indeed, contrary to the accepted view that common law courts had never been hospitable to mercantile cases and only began, about 1600 , very gradually to assimilate the law merchant. However, as has been indicated, merchants, even alien merchants, used the court of King's Bench in the 14th century, note 28 supra. While it has been said that the common law courts were not too receptive to mercantile cases in Coke's time, they did try, oddly enough, to get the business of the courts such as Admiralty that were so receptive. Moreover, the merchant's jury was allowed, note 31 supra. It may be that far too much reliance has been put on the phrasing in the reports as telling us what the law, as it was actually practiced, was. The reports are acknowledged to be abominable for this period, and the actual situation was probably far more complex than they indicate. For example, individual judges may have exercised considerable discretion in applying mercantile law or using juries of merchants. It does seem probable, however, that there was considerable friction between merchants and the central common-law courts.

${ }^{43}$ The struggle is fully discussed in 1 Holdsworth, op. cit. supra note 4 , at 508-16, 553-58, 610-11; 5 id., at 412-93. 
within the office of assurances within the city of London." 44 This commission, however, had a brief and unsuccessful existence. ${ }^{45}$

In addition to the courts of the realm, merchants were developing during this period a variety of private tribunals for the settlement of their disputes. These arose chiefly in connection with the rapidly developing trading companies. As has been indicated, the typical merchant was no longer an itinerant peddler with all his belongings packed on his back or those of his animals. Rather, he was an established businessman in a seaport who sent out cargoes of native products to exchange for foreign goods. ${ }^{46}$ More frequently merchants pooled their goods and formed trading companies to export these goods. This change was aided by the growth of nationalism and by the extension of direct trade by Englishmen to diverse and widely separated lands. These factors made it desirable to have an organization to protect and advance one's interests in the foreign land.

The companies were of two types: "regulated" and "joint-stock"; the regulated being the earlier type. Both could operate only under a royal charter authorizing them to trade within a particular area. In the case of the regulated company, each member traded individually on his own account. There was no sharing of profits or losses. There might be, and usually was, a sharing of expenses of ships and other trading facilities. In the case of the joint-stock company, each member invested an amount of capital and shared in the profits or losses according to the proportion his share bore to the total capital. Initially, the entire capital was distributed at the conclusion of each venture. No Englishman could trade in the designated area unless he was a member of the company and the latter tried with varying success to gain charters from foreign rulers giving them a monopoly of all trade in the area. A standard feature of the English charter was a provision for settlement of all intracompany disputes by a company tribunal composed of member merchants. It is clear that many of the commercial disputes which arose among English merchants were settled by these tribunals. ${ }^{47}$ In addition, there is some indication that private arbitration was employed by merchants. Malynes, writing in 1651, urged arbitration as the most desirable method of settling mercantile disputes. ${ }^{48}$

443 Eliz. I c. 12 (1601), amended 13, 14 Charles II c. 23 (1662).

451 Holdsworth, op. cit. supra note 5 , at 571 .

${ }^{45}$ See note 32 supra.

${ }^{47}$ See note 35 supra. See also Schmitthoff, The Origin of the Joint Stock Company, 3 U. of Toronto L. J. 74 (1939); 8 Holdsworth, op. cit. supra note 4, at 206-22; Clapham, op. cit. supra note 7 , at $262-72$.

${ }^{48}$ Malynes, Consuetudo, Vel Lex Mercatoria, or, The Ancient Law Merchants 311 (1656). "Merchants causes are properly to be determined by the Chauncerie, and ought to be done with great expedition: but it falleth out otherwise, because they are by commissions commonly referred to Mferchants, to make report of the state thereof unto the Lord Chancellor; for the customs of Merchants are preserved chiefly by the said court, and above al things Mer- 
Thus, during the Tudor period as during the medieval, merchants and their law were to be found throughout the complex and disorganized English judicial system. It appears, however, that there was an emerging tendency on the part of merchants to avoid the more important common law courts, i.e., the courts at Westminster, which were becoming more inflexible in their jurisdiction, and to use their own tribunals.

$$
\text { THE WHIG ERA, I640-I800 }
$$

During the succeeding period from 1640 to 1800 , this estrangement between the merchants and the common law courts reached its apogee, although nominally this was the period in which, after centuries of separation, the common law finally assimilated the Law Merchant. This was also the period during which England established her commercial supremacy over the world, and it saw the beginning of her industrial dominance. It was a period of great change and development in every field of life and thought. Among these was the change in the structure of the trading community. It was, at least during the 18th century, the period of the individual merchant or mercantile firm. With the exception of the East India Company, which was becoming a quasigovernmental organization, the trading companies disappeared or fell into substantial desuetude. In their place, individual merchants, or a few merchants associated in partnership, traded on their own account, frequently by means of correspondent firms or agents in foreign communities. ${ }^{49}$

How merchants settled their disputes in this period is a difficult question. ${ }^{50}$ The medieval institutions had, by this time, completely disappeared. The prerogative courts of the King-such as the Star Chamber and the Councilhad been abolished during the Commonwealth and the jurisdiction of the Admiralty was severely limited. ${ }^{51}$ The superior courts of common law in the century preceding Lord Mansfield's term as Chief Justice of King's Bench were little used by merchants. ${ }^{52}$ And it does not appear that they were used

chants affaires in controversie ought with all brevitie to be determined, to avoid interruption of trafficke which is the cause that the Major of the Staple is authorized by severall Acts of Parliament to end the same, and detaine the same before him, without any dismission of the Common-Law, which sheweth the necessarinesse of the Office of Prior and Consulls before mentioned."

${ }^{49}$ The 18th century mercantile community is generally discussed, inter alia, in Westerfield, Middlemen in English Business 329-62 (1915); Moffit, England on the Eve of the Industrial Revolution 216-48 (1925). See also Sutherland, A London Merchant, 1695-1774 (1933); Fay, Great Britain from Adam Smith to the Present Day 123-50 (1928).

50 For a general discussion of the subject see Sutherland, The Law Merchant in England in the Seventeenth and Eighteenth Centuries 149 (1934), although she is more interested in the doctrinal development of the law merchant from customs and the like.

51 Holdsworth, op. cit. supra note 4 , at $515 ; 6$ id., at 112.

52 Thus Fifoot writes: "The first volume of Shower's Reports, covering the reign of William III, contains 265 cases. Of these 140 deal with procedure, 30 with questions of property, 23 with the issue of Prerogative Writs, and only 12 with cases which can be said to raise points 
much during Mansfield's time on the bench except in certain narrowly defined areas. ${ }^{53}$

It seems probable that merchants used the lesser common law courts, particularly the Lord Mayor's Courts of the principal towns, where they controlled, and indeed constituted, the government. It is known that the Lord Mayor's Court of London handled a great variety of commercial cases in the latter half of the 17th century. ${ }^{54}$ The East India Company had something analogous to a claims adjustment bureau for those who purchased goods from it, and since it had a monopoly of the trade with India, this was, presumably, a fairly important forum for settling disputes. ${ }^{55}$

Merchants also made extensive use of private voluntary arbitration. This procedure, of course, had been employed for centuries, but there are several indications that during this period it was much more widely used than previously. ${ }^{56}$ One of these indications was the enactment of an arbitration statute in 1697. This provided that arbitration awards should be made rules of court and enforced as such upon motion if there were agreements to that effect by the parties in their submission of a dispute to arbitration. The preamble to the act states:

... for promoting trade, and rendering the awards of arbitrators the more effectual in all cases, for the final determination of controversies referred to them by merchants and traders, or others, concerning matters of account or trade, or other matters. ...57

of commercial interest. Of the cases reported in the first two volumes of Salkeid between the years 1689 and 1712,270 deal with procedure (including 33 on evidence), 116 with the Land Law or the administration of estates, 88 with Prerogative Writs, and 78 with the Poor Law. To balance these formidable figures can be cited only 20 cases upon negotiable instruments, 8 upon marine insurance, 8 upon bankruptcy, and 20 collected under the title 'Action sur le Case sur Assumpsit.'

"Mercantile influence, however, if not a dominant, was a significant, factor in the courts, and its pressure grew more insistent as the century progressed. Between 1690 and 1750, 136 cases were reported on negotiable instruments and 48 on marine insurance. The statute of William III introduced a tolerable business in arbitration awards, and Westminster Hall echoed, at a chaste distance, the speculative orgy which culminated in the collapse of the South Sea Company." Fifoot, op. cit. supra note 28, at 13.

${ }^{53}$ See note 5 supra.

54 See Anderson, New Light on Warranty of Quality of Goods 1350 to 1800 (unpublished thesis submitted for the degree of Master of Laws at the Columbia Law School, located in the Columbia Law Library, filed as Treasure Thesis) in which many of these cases are reprinted.

${ }^{55}$ Id., at 42: "We found that great monopoly (the East India Company) voluntarily making adjustments with disappointed buyers whose goods were defective, not in conformity with the sample, not in accord with the description, not merchantable, and falsely packed. ..." He gives as some examples of commodities involved, indigo, pepper, silk and cinnamon.

${ }^{66}$ Thus an offer to arbitrate a dispute is found in Iondon as early as 1327, Calendar 13231364 , op. cit. supra note 26, at 20; see also Sayre, Development of Commercial Arbitration Law, 37 Yale L. J. 595, 597-98 (1928); and Malynes, op. cit. supra note 48.

679 \& 10 William III c. 15 (1697). 
There were also many references to arbitration in books which were published on trade during the period. Perhaps the most striking is from that "idyll of the Bourgeoisie," 58 Defoe's Compleat English Tradesman. ${ }^{59}$

Who cares to deal with a Tradesman that is always tormenting them with Cavils and Quarrels, wrangling for trifles, and going to Law for meer Shadows of Difference, as if he sought Advantages, and quarreled for the sake of Quarreling? The best Customers will always shun trading with such a Man. ${ }^{60}$ [T] he honest peaceable Tradesman, will, as far as in him lies, prevent a Decision at Law; if it be possible, he will bring all Differences to a friendly Accomodation, by Expostulation, by Application, by Arbitration, nay, and even abating sometimes much of his Demands for Peace sake. When two tradesmen of this Pacific Temper meet, A Reference never fails to put an End to all Disputes between them: A Man that means Honestly, is never afraid or asham'd to refer all his Differences to the next unbias'd and indifferent Man he meets: He embraces all Occasions of bringing such Things to an amicable peaceable Conclusion. ... ${ }^{61}$ If both are peaceably inclin'd, a grave Neighbour of a healing Disposition, such a Compleat Tradesman as I describ'd in the last Chapter, who having left off Business with Reputation, and particularly with the Reputation of a Man of Sense and Temper: Such a one being call'd in, never fails to make up the Breach, to reconcile all the Differences, and shew them how easily they might, with the Help of a little Moderation, have done it without him. ${ }^{62}$

What weight can be given to Defoe as an authority for mercantile practice at the time is very doubtful. For one thing, his book quite explicitly excluded "merchants," in the sense of those who trade beyond the seas; ${ }^{63}$ for another, he was writing a sermon on how trade ought to be conducted, and he had failed in trade himself. Still, it seems probable that his statements reflected in some measure contemporary practice. In any event it is the only authority of the time that treats the subject in such detail. Another indication of the popularity of arbitration is the inclusion of forms for arbitration agreements and awards in form books and manuals designed for tradesmen and their clerks. ${ }^{64}$ There also began to appear, during this period, numerous legal text-

${ }^{58}$ So called in Tawney, Religion and the Rise of Capitalism 252 (1926).

${ }^{59} 2$ Defoe, The Compleat English Tradesman (1727).

$$
\begin{array}{ll}
{ }^{60} \mathrm{Id} \text {., at } 281 . & { }^{62} \mathrm{Id} \text {., at } 289 . \\
{ }^{61} \mathrm{Id} \text {., at } 288 . & { }^{63} \mathrm{Id} \text {., at 2, } 3 .
\end{array}
$$

64 For example, Clare, Youth's Introduction to Trade and Business 132-34 (1751)(Forms of "A Condition to attend the Award of Arbitrators" and "The Form of Umpirage of Award"); Hatton, The Merchant's Magazine: or The Tradesman's Treasury 257 (8th ed., 1726) ("An Arbitration Bond, with a Condition thereto annex'd"); 1 Montefiore, The Trader's and Manufacturer's Compendium 49-62 (2d ed., 1804)(discusses arbitration and gives examples of "Arbitration Bond," an amendment of same "when there is to be an umpire," "Agreement to extend time for making an Award," "The Nomination of an Umpire," "Award by Two Arbitrators," and "An Award of an Umpire chosen by the Arbitrators.") 
books on arbitration. ${ }^{65}$ The first, according to Holdsworth, ${ }^{66}$ was published anonymously in 1694 . One rather significant reference to mercantile tribunals and arbitration occurs in Sir Josiah Child's $A$ New Discourse on Trade, ${ }^{67}$ wherein he suggested:

That it be enacted, that there shall be erected within the city of London, a standing court-merchant, to consist of twelve able merchants, such as shall be chosen by the livery men of the said city in their common hall, at the time and in the manner hereinafter limited and appointed. 68

Sir Josiah's recommendations were echoed by others before and after the publication of his book. ${ }^{69}$ Yet, interestingly enough, nothing was ever done

${ }^{65}$ For example, Bacon, The Compleat Arbitrator; or The Law of Awards (3d ed., 1770); Kyd, A Treatise on the Law of Awards (2d ed., 1799); Jacob, Lex Mercatoria, or The Merchants Companion 27, 47-50, 309, 321, 340 (2d ed., 1729); 2 Molloy, De Jure Miaritimo et Navali (9th ed., 1769) 305-11; 1 Beawes, Lex Mercatoria 498-506 (6th ed., Chitty, 1813); 3 Blackstone, Commentaries on the Laws of England 16-17 (8th ed., 1778).

6612 Holdsworth, op. cit. supra note 4, at 392-93.

${ }^{67}$ Child, A New Discourse on Trade (5th ed., 1751). "I have conceived great hopes from the late most prudent and charitable institution of that judicature, for determination of differences touching houses burning by the late fire in London, that this kingdom will at length be blessed with a happy method, for the speedy, easy, and cheap deciding of differences between merchants, masters of ships, and seaman, \&c. by some court or courts or merchants, like those which are established in most of the great cities and towns in France, Holland, and other places; the want of which in England, is, and has ever been, a great bar to the progress and grandeur of the trade of this kingdom; as for instance, if merchants happen to have differences with masters and owners of ships, upon charter-parties, or account beyond sea, \&c. the suit is commonly first commenced in the admiralty court, where, after tedious attendance and vast expences, probably just before the cause should come to determination, it is either removed into the delegates, where it may hang in suspence till the plaintiff and defendant have empty purses and grey heads, or else, because most contracts for maritime affairs, are made upon the land, (and most accidents happen in some rivers or harbours here, or beyond sea, and are not in Alto mari) the defendant brings his writ of prohibition, and removes the cause into his Majesty's court of king's bench, where after great expences of time and money, it is well if can make our own council, being common lawyers, understand one half of our case, we being amongst them as in a foreign country, our language strange to them, and theirs as strange to us; after all, no attestations of foreign notaries, nor even public instruments from beyond sea, being evidences at law, and the accounts depending, consisting perhaps of an hundred or more several articles, which are as so many issues at law, the cause must come into Chancery, where after many years tedious travels to Westminster, with black boxes and green bages, when the plaintiff and defendant have tired their bodies, distracted their minds and consumed their estates, the cause, if ever it be ended, is commonly by order of that court referred to merchants, ending miserably, where it might have had at first a happy issue if it had begun right." Id., at 99-100.

${ }^{68}$ Id., at 101.

${ }^{69}$ Bethel, An Account of the French Usurpation upon the Trade of England 22 (1679); Justice, A General Treatise of Monies and Exchanges 73-82 (1707); Baston, Observations on Trade and a Publick Spirit 67-88 (2d ed., 1728) (an ardent Protestant, he regards lawyers as "in one Sense much worse than the lazy Priests before spoken of, as the first being passive Rogues, the other active ones." Id., at 88); Cary, A Discourse on Trade 26-27 (1745); Decker, An Essay on the Cause of the Decline of the Foreign Trade 61-62 (4th ed., 1751); Cary, Essai Sur L'Etat du Commerce d'Angleterre 301-2 (1755). 
about it, although it would seem that the merchants of London in the Age of Mercantilism could certainly have obtained such a court if they had really made an effort to get one from Parliament. One can only suppose that there was no general desire among merchants for a special court. In connection with the suggestions for a separate mercantile court it is interesting to refer to Jeremy Bentham and to note that, so far as can be determined, he makes no reference to these proposals, although he was acquainted with, and very sympathetic towards, the needs of trade. He does mention arbitration several times, generally to show the inadequacies of the court system. ${ }^{70}$ As a remedy for an inadequate judiciary, he felt that arbitration had, on the whole, failed. He did, however, provide for arbitration in his proposed constitution. He suggested its use in the case of long accounts between merchants. ${ }^{71}$ The context indicates that he believed voluntary arbitration by merchants was limited almost exclusively to the long account situation and here performed a useful function.

Bentham's apparent apathy for merchant juries was not shared by Lord Mansfield, whose use of merchant juries is famous. As one of his biographers has written:

The collaboration of judge and merchant, if it was to exercise its due influence upon the law, required adequate channels of communication. In the development of the special jury Lord Mansfield found the vital medium. . . . But its use Iong remained spasmodic and without system. . . Lord Mansfield converted an occasional into a regular institution, and trained a corps of jurors as a permanent liaison between law and commerce. ${ }^{72}$

These special juries composed of merchants were used by the common law courts in mercantile cases as late as 1806 , almost twenty years after Mansfield had completed his task of assimilation and left the bench. ${ }^{73}$

Apart from the various formal methods of adjudication, it seems likely that the majority of mercantile disputes were settled by means of negotiation

\footnotetext{
702 Bentham, Collected Works 122 (Bowring ed., 1843) (cases involving accounts usually go to arbitrators); 3 id., at 329-30 (complex cases coming to court are referred to arbitrators); 5 id., at 203 (arbitration statute and its ineffectiveness); 5 id., at 469 (mentioned); 5 id., at 521 (disadvantages of arbitration); 6 id., at 481 (arbitration is supposed to be beneficial but is in fact ineffective).

719 id., at 552-53.

72 Fifoot, op. cit. supra note 28, at 104-5.

${ }^{73} 5$ Bentham, Collected Works (Bowring ed., 1843). "Does your Lordship feel any such curiosity, as that of knowing the number absolute, and relative, of these causes in which justice is paid for and not done... accept at my hands what chance presents to them: Times Newspaper, 16th December 1806- Yesterday morning, in the Court of King's Bench, Guildhall, eight causes for special juries appeared on the list for trial. They were all referred: in one only a verdict was taken, pro forma for the plaintiff.' The whole number without exception -in all of them justice paid for-in all of them justice deniedl . . The causes, London causes, and those special jury causes; therefore mercantile causes of the highest order:-causes naturalIv attended with a large measure of complication." Id., at 36.
} 
among the parties. To be sure, this is probably always the case. The nature of the English mercantile community during this period, however, would seem to make this procedure even more important than would ordinarily be the case. It was, as has been stated, a community of well established merchants who traded for the most part individually. They were not, generally, specialized traders; they dealt in almost every commodity, or were prepared to do so. Their relations with each other would doubtless last for a long period of time and be fairly complex with many buying and selling transactions on each side. A law suit, or even a formal arbitration proceeding, would tend to destroy a relationship of this kind, and hence would be avoided by the wise merchant.

Thus, it would appear that during this period, although English merchants continued to have a great variety of tribunals available with the prevalent merchant juries and in some cases merchant judges, the tendency was away from formal adjudication, and toward a private system of adjudication either by arbitration or negotiation. Indeed, there was a clear refusal to press for the establishment of an official mercantile court similar to those that existed on the continent.

\section{The British North American Colonies, $1600-1800$}

The title of this section is, in many ways, a misnomer, for almost all the material on which the work is based comes from New York, and it is, of course, questionable to generalize about the colonies as a whole from the experience of any one of them. ${ }^{74}$ All of the colonies had peculiar local features shared by no other colony. On the other hand, they also had a great many features in common. Foremost among these was the fact that by the middle of the 18th century at least, they were all British colonies regardless of their national origin. Their language, their government, and even their churches were predominantly influenced by England. Their business as well as their political capital was London, and their trade was principally within the orbit of the British Empire. ${ }^{75}$ Consequently, in matters of trade practices, there was a high degree of uniformity among the colonies. Also of particular significance is the strong influence of the English courts and law on the colonial court system. ${ }^{76}$

${ }^{74}$ See Llewellyn, reviewing Morris, Studies in American Legal History, 31 Col. L. Rev. 729 (1931).

${ }^{75}$ As to the economic activities of the colonies generally, see Wright, Economic History of the United States 132-58 (1941); Faulkner, American Economic History 75-84 (6th ed., 1949).

${ }^{76} \mathrm{It}$ would appear that all, or nearly all, the colonial courts used arbitration. See Mayers, The American Legal System 543 n.1 (1955); Aumann, The Changing American Legal System 48-50 (1940); Early American Arbitration, 1 Arb. J. 51 (1946); Odiorne, Arbitration Under Early New Jersey Law, 8 Arb. J. 117 (1953). 
In New York the situation appears to have been very similar to that in England. Specifically, merchants used at one time or another every type of court available in the colony to settle their disputes, and from time to time they devised new forms for their own use. Especially popular was the Mayor's Court of New York City, which was modeled on the Lord Mayor's Court of London, although it also had Dutch antecedents. ${ }^{77}$ As in England the Mayor's Court employed the procedure of reference: an action would be brought in court and then referred by the court to a referee or arbitrator for decision, generally, it would seem, by the consent of the parties. ${ }^{78}$ In 1767 , however, the legislature enacted a statute which provided for the compulsory reference of cases involving long accounts. ${ }^{79}$ The New York merchants also used private voluntary arbitration. This practice was especially prevalent in maritime cases, both those involving marine insurance and those involving the distribution of the loot from prizes, the latter being one of the more important branches of local commerce. ${ }^{80}$ Indeed, an early American insurance policy issued in Boston includes a clause for the arbitration of disputes arising under it. $^{81}$ The prevalent use of this device is indicated in the letters of merchants ${ }^{82}$ and in newspapers ${ }^{83}$ of this period. Furthermore, advertisements in news-

${ }^{77}$ Morris, Select Cases from the Mayor's Court 1674-1784, 40-43 (1935).

${ }^{78}$ See, for example, Van Swieten v. Grevenraed( $\left.t\right)$ in Minutes of the Supreme Court of Judicature of the Province of New York 1691-1704. Collections of the New York Historical Society for 1946, 57 (Hamlin and Baker ed., 1952).

${ }^{79}$ Act of 31 December 1768, 4 Colonial Laws of New York 1040. It is interesting to note that this is the situation in which Bentham recommended arbitration.

${ }^{80}$ See, for example, letter of Gerard G. Beekman to the Rhode Island firm of Vernon and While of 18 th July 1746 in New York Historical Society Publications 1954, The Beekman Mercantile Papers, 1 Gerard G. Beekman Letter Book 3 (White, ed.). Beekman wrote in connection with the division of a prize cargo: "Shall consult them What person to Chuse of your side to (deter)mine what poroportion (sic) your Vessell shall draw of this (Pri)ze as it will be left to three Indifferent men...." The history of arbitration in New York is treated in somewhat more detail in Jones, Three Centuries of Commercial Arbitration in New York: A Brief Survey [1956] Wash. U. L. Q. 193.

81 Gras and Larson, Casebook in American Business Fistory 144 (1939).

${ }^{82}$ See note 78 supra. Id., at 5, 378, 410, 414, 427; Letterbook of the firm of Greg and Cunningham (manuscript in the New York Historical Society) 9, 14, 33, 61, 147, 165, 149, $209,211,235,240$; Collections of the New York Historical Society for the year 1928, Letter Book of John Watts, 107, 108, 284, 285.

${ }^{83}$ For example, see New York Weekly Post Boy of 21 January 1745: "The Arbitrators for Settling the Differences between the four Privateers formerly arrived here with Six French Prizes will meet at the House of Robert Todd every Friday Evening til the whole is settled"; and in the New York Gazette of 15th March 1731: "Whereas it is industriously reported about this province that the Reverend $\mathrm{Mr}$. William Vesey has offered to leave the Matters in Difference between him his Nephew Joseph Penniman and myself to the Arbitration of honest Men, and that I refused so to do I now take the liberty to inform all Persons, that $I$ have both by word of Mouth and in Writing sundry Times offered to the said Mr. Vesey to have all Things in Dispute to the final Determination of any Merchant or Merchants in this City, and did propose for myself, to give good Security for the Performing all Things so determined, on Condition that they would do the like...." 
papers for stationers and scriveners show the availability of English books on arbitration, arbitration forms, and the services of a practiced scribe for the preparation of accounts for arbitration. ${ }^{84}$

In 1768 the merchants organized the New York Chamber of Commerce. One of the Chamber's stated purposes was to provide for the settlement of disputes among its members, and one of its first acts was to set up an arbitration committee. ${ }^{85}$ The entire Chamber suspended operations during the first part of the Revolution, but in 1778 the Tories, or at least those merchants who remained in New York during the British occupation, reestablished the Chamber, including therein an arbitration committee. ${ }^{86}$ Indeed, the Arbitration Committee of the Chamber was apparently the only operative civil court in New York City during the British occupation. ${ }^{87}$ Interestingly enough, an effort was made in 1770 by one of the Chamber members to have arbitration compulsory on the members, but the motion failed to pass. ${ }^{88}$ This would seem to indicate that while the New York merchants thought it desirable to have available their own special mercantile tribunal, they did not wish to be limited to it.

While, as has been pointed out, one cannot generalize about the colonies as a whole from the situation in any one colony, it would appear that conditions in the other colonies were similar. Letters from merchants in New York to merchants in New Brunswick, ${ }^{89}$ Rhode Island, ${ }^{90}$ and the Barbados ${ }^{91}$ indicate that arbitration was a widespread practice in the colonies. Thus it is safe to say that in the North American Colonies, as in England, merchants made use of many forms of dispute settling procedures, including courts and arbitration, all invoking the use of expert determination.

\section{THE NINETEENTH CENTURY IN GREAT BRITAIN AND THE UNITED STATES}

Statistics are not available and it is doubtful that they ever will be, but it is probable that in the nineteenth century arbitration in one form or another became the most important form of mercantile dispute settlement both in

84 For example 6th May 1745 (accounts stated for arbitration); 21st December 1747 (Printer advertises arbitration bonds). 1867).

${ }^{85}$ Colonial Records of the New York Chamber of Commerce 1768-1784, 3 (Stevens ed.,

${ }^{86}$ Id., at 204.

${ }^{87}$ See Earliest Arbitration Records of the Chamber of Commerce of the State of New York 4 (1913); see also, for example, "Peter Campbell agt. John Walker \& William Heath," id., at 11 .

${ }^{88}$ Colonial Records of the New York Chamber of Commerce 1768-1784, 73-74 (Stevens ed., 1867).

${ }^{89}$ Letter Book of Greg and Cunningham, op. cit. supra note 82, at 165.

90 See note 80 supra.

${ }^{9}$ Letter Book of John Watt, op. cit. supra note 82, at 107. 
the United States and in Britain, although courts continued, of course, to be used. Further, it appears that in this country, and probably in Britain, the most important form of arbitration was that which existed in connection with mercantile organization. In England the 1697 Arbitration Act was amended several times, eventually in 1889 to provide that agreements to arbitrate future disputes were enforceable. ${ }^{92}$ It was estimated by the end of the century that almost all mercantile cases, even those that eventually came to the courts, went to arbitration. ${ }^{93}$ Exchanges such as the Liverpool Cotton Exchange, the London Stock Exchange, the London Corn Trade Association, and the Coffee Trade Association, had machinery for arbitration. ${ }^{94}$ In the United States exchanges and mercantile associations proliferated throughout the century. The New York Chamber of Commerce has been mentioned. It continued to provide arbitration for its members until late in the century. ${ }^{95}$ The New York Stock Exchange was formed in 1792. In Rule 17 of its Constitution of 1817 , it provided in effect for the compulsory arbitration of disputes among its members by the Board of the Exchange. ${ }^{96}$ The New York Produce Exchange was formed in 1861 and it had a similar provision in its by-laws. ${ }^{97}$ Many other exchanges were formed in New York in this period with similar provisions in their charters, such as the Mercantile Exchange (1882), ${ }^{98}$ the Cotton Exchange (1871), ${ }^{99}$ and the New York Coffee \& Sugar Exchange (1885). ${ }^{100}$ This development was not limited to New York. The Chicago Board of Trade was formed in 1848 and has provided arbitration from its earliest days. Others were the St. Louis Merchants Exchange, Philadelphia Commercial Exchange (1854), Kansas City Board of Trade (1865), Milwaukee Grain Exchange (1858), and many others. ${ }^{101}$ Toward the end

${ }^{92} 52$ \& 53 Vict. c. 49 (1889).

${ }^{93}$ Rosenbaum, A Report on Commercial Arbitration in England, 12 American Judicature Society 11, 12 (1916).

${ }^{94} \mathrm{Id}$., at $15-17$.

${ }^{95}$ Bishop, A Chronicle of One Hundred and Fifty Years 122-23 (1918).

${ }^{96}$ Stedman, The New York Stock Exchange 65 (1905).

${ }^{97}$ The name was originally the New York Commerical Exchange. It was changed to the New York Produce Exchange in 1868. The immediate predecessor of the Commercial Exchange was formed in 1852 under the name of the New York Corn Exchange, and there were previous unorganized exchanges reaching back to the beginnings of the town of New Amsterdam. See 38 Annals 524-44 (1911) and Mund, Open Markets 112-13, 115-18 (1948). The original by-laws of the New York Commercial Association are in manuscript in the archives of the New York Produce Exchange.

${ }^{98}$ Charter and By-Laws of the New York Mercantile Exchange (1949).

${ }^{99}$ Charter of the New York Cotton Exchange, Act of 8 April 1871, N.Y.L. (1871) c. 365.

${ }^{100}$ Originally the New York Coffee Exchange, the Charter of which is the Act of 2 June 1885 N.Y.L. (1885) c. 393.

${ }^{101} 38$ Annals 320-21, 545-70 (1911). 
of the century trade associations were formed and they likewise provided for arbitration, frequently compulsory, of disputes among their members. Prominent among these associations were the Grain \& Feed Dealers National Association (1896), the National Hay Association (1895), National Cotton Seed Products Association (1896), and the American Seed Trade Association (1883).

New York enacted a facsimile of the 1697 English Arbitration Act in $1791,{ }^{102}$ and this act and amendments thereto continue to the present day. As far as one may determine from the reported cases, however, mercantile disputes, if they went to arbitration, did not come into the courts. The arbitrations which were reviewed by the courts were generally of a non-mercantile nature. ${ }^{103}$

Thus in the nineteenth century there was a development of special private mercantile tribunals in which the bulk of mercantile disputes was settled entirely outside the state judicial system. The indications are that this trend has continued and exists today in a strengthened form.

\section{CONCLUSION}

As has been seen, merchants in Great Britain and the United States have used every sort of tribunal from the courts held in fairs under the auspices of abbots at a time when the church was supposedly hostile to commerce, and the hated instruments of Stuart absolutism such as the Star Chamber, to their own committees in the 19th century trade associations and exchanges. In all of these tribunals, the actual decision of the case seems to have been by merchants. Sometimes the tribunal itself was composed of merchants, as in the staple courts and arbitration committees of exchanges and trade associations. Until the 19 th century, the more usual practice seems to have been

$$
{ }^{102} \text { N.Y.L. (1791) c. } 20 .
$$

${ }^{103} \mathrm{An}$ attempt was made to read all of the cases decided and reported in New York Courts from 1790 to 1920 which involved arbitration. 302 cases were found and it is believed that these represent substantially all of the cases that there were. They have been classified according to the subject matter in controversy as follows: Land-88; Construction-40; Sales \& Freight-19; Personal Contracts-32; Torts-10; Insurance-16; Miscellaneous-36; Unknown-61. "Land" cases principally involved boundary disputes; "construction" cases are those involving contracts to build various structures; "sales \& freight" involved sales of goods and the shipping of goods. The sales were predominately, as indicated in the text, single transactions and involved such commodities as building stone, wagons of apples, or other farm produce, logs and the like. "Personal Contracts" are chiefly partnership and agency agreements. "Torts" include everything from assault to slander. "Insurance" is chiefly fire insurance. "Miscellaneous" varied from claims owing to one who performed detective work for another to bastardy claims. The category "Unknown" refers to those cases in which it is impossible to determine from the report of the case the subject matter of the dispute. The only interesting trends are insurance, torts and construction. There are only two cases involving insurance prior to 1870 . There were 11 construction cases prior to 1880 and 33 after. It seems probable that arbitration clauses were standard in construction contracts and insurance policies. 
to use a merchant referee or a jury of merchants. But it has always been actual practicing merchants who have finally decided the bulk of mercantile cases with little, if any, control by courts. Certainly this is true today with the very widespread and growing use of arbitration.

It obviously follows that there is, and has always been, a large area of commercial life where the "law" as announced by courts has effect only indirectly if at all. This fact should be of interest to students of commercial law, for it is clear that in many instances it is unimportant to know what the "law" is, in the sense of being able to predict what courts will do in a particular situation. What is needed is a knowledge of what the merchants who will decide the case will do. The decision reached may be very different depending on the forum which is used. It is said, for instance, that arbitrators in the textile industry in New York will often disregard the terms of the contract, such as disclaimers of warranty, where they conflict with customs or practice of the trade. ${ }^{104}$ Presumably, this is true elsewhere as well. Lawyers advising clients in this area consequently should, and probably do, take this fact into account, but not too much notice seems to be taken of it in published discussions of commercial law.

Moreover, the existence of this continuous insistence by merchants on selfadjudication should be of interest to students of business. It is surely an important element of the organization of the mercantile community. It would seem possible also that the existence of this tendency in the mercantile community may point to similar practices in other communities. Such groups as churches, universities, trade unions and professional groups, certain ethnic organizations, and the like, may very well settle most of the disputes among their members in a way largely uninfluenced by the "law" as set forth by the courts of the formal legal system. If they do, then it would seem that the concept of the courts of the state as the primary place to which its citizens resort for the adjudication of their differences should be revised. In any event, it is clear that all studies of commercial law should take into account the possibility that the law which really governs the situation is not to be found in the decisions of courts.

${ }^{104}$ This information has been obtained by the University of Chicago Law School in its research into commercial arbitration. 